Article

\title{
Setting Thresholds to Define Indifferences and Preferences in PROMETHEE for Life Cycle Sustainability Assessment of European Hydrogen Production
}

\author{
Christina Wulf * ${ }^{\mathbb{D}}$, Petra Zapp, Andrea Schreiber $(\mathbb{B})$ and Wilhelm Kuckshinrichs $(\mathbb{C}$
}

\section{check for}

updates

Citation: Wulf, C.; Zapp, P.; Schreiber, A.; Kuckshinrichs, W. Setting Thresholds to Define Indifferences and Preferences in PROMETHEE for Life Cycle Sustainability Assessment of European Hydrogen Production. Sustainability 2021, 13, 7009. https://doi.org/10.3390/su13137009

Academic Editors: Antonio Valente and Diego Iribarren

Received: 20 May 2021

Accepted: 17 June 2021

Published: 22 June 2021

Publisher's Note: MDPI stays neutral with regard to jurisdictional claims in published maps and institutional affiliations.

Copyright: (c) 2021 by the authors. Licensee MDPI, Basel, Switzerland. This article is an open access article distributed under the terms and conditions of the Creative Commons Attribution (CC BY) license (https:// creativecommons.org/licenses/by/ $4.0 /)$.
Forschungszentrum Jülich, Institute of Energy and Climate Research-Systems Analysis and Technology Evaluation (IEK-STE), 52428 Jülich, Germany; P.Zapp@fz-juelich.de (P.Z.); A.Schreiber@fz-juelich.de (A.S.); W.Kuckshinrichs@fz-juelich.de (W.K.)

* Correspondence: C.Wulf@fz-juelich.de

\begin{abstract}
The Life Cycle Sustainability Assessment (LCSA) is a proven method for sustainability assessment. However, the interpretation phase of an LCSA is challenging because many different single results are obtained. Additionally, performing a Multi-Criteria Decision Analysis (MCDA) is one way-not only for LCSA — to gain clarity about how to interpret the results. One common form of MCDAs are outranking methods. For these type of methods it becomes of utmost importance to clarify when results become preferable. Thus, thresholds are commonly used to prevent decisions based on results that are actually indifferent between the analyzed options. In this paper, a new approach is presented to identify and quantify such thresholds for Preference Ranking Organization METHod for Enrichment Evaluation (PROMETHEE) based on uncertainty of Life Cycle Impact Assessment (LCIA) methods. Common thresholds and this new approach are discussed using a case study on finding a preferred location for sustainable industrial hydrogen production, comparing three locations in European countries. The single LCSA results indicated different preferences for the environmental, economic and social assessment. The application of PROMETHEE helped to find a clear solution. The comparison of the newly-specified thresholds based on LCIA uncertainty with default thresholds provided important insights of how to interpret the LCSA results regarding industrial hydrogen production.
\end{abstract}

Keywords: hydrogen; life cycle sustainability assessment; multi-criteria decision-analysis; PROMETHEE

\section{Introduction}

The transformation of the energy system is of high importance to meet the goals of the Paris agreement [1]. Innovative energy technologies are necessary to make a considerable contribution to this transformation process. Hence, the European Commission proposed the European Green Deal, a concept for Europe to become climate neutral by 2050 and to transform the EU's economy in a sustainable manner [2]. Preceding this, the EU published the Hydrogen Roadmap Europe [3] in 2019. Hydrogen, as a secondary energy carrier, is discussed frequently in energy transformation scenarios, e.g., [4,5]. It is easier to store than electricity, can be directly used as feedstock, or can help to electrify several other sectors besides the energy sector, e.g., mobility or industry. However, hydrogen should only be used if a direct electrification is hard to achieve, e.g., large battery demand for heavy-duty vehicles or demand of a very steady heat source in the glass industry, because of the lower efficiency of hydrogen applications compared to direct electrification.

In order to analyze greenhouse gas reduction potentials without losing track of other associated effects, a comprehensive sustainability assessment is necessary. In addition to other environmental impacts, this should also include economic as well as social implications [6]. The Life Cycle Sustainability Assessment (LCSA) is one approach for a holistic assessment of emerging technologies [7]. The interpretation phase of an LCSA, however, 
is challenging, because many different single results are obtained and it is not easy to propose one unambiguous solution. For scientific communities, it might be interesting to discuss them separately in detail and the UNEP/SETAC even recommends to do so [7]. For decision-making processes and for audiences not too familiar with the single-impact categories, this seems even more challenging. To structure and guide decision-making processes in this context, the Multi-Criteria Decision Analysis (MCDA) has been developed. The MCDA comprises mathematical approaches to cluster the wide number of individual results to fewer but more manageable results [8,9]. One well-known method is the weighted sum approach, which is very easily manageable but fails to cover more complex decision-making contexts. In contrast, elaborated MCDA approaches such as the Technique for Order of Preference by Similarity to Ideal Solution (TOPSIS), Preference Ranking Organization METHod for Enrichment Evaluation (PROMETHEE) or Elimination Et Choix Traduisant la REalité (ELECTRE) are able to address complex problems. Regardless of which method is to be used within the MCDA guidance process, fundamental value-based choices have to be made. One mandatory decision is to what extent compensation between indicators is allowed [10]. One class of non-compensatory methods is based on outranking of the different options assessed, e.g., PROMETHEE.

Irrespective of compensations, for options where the indicator results are close to each other, often no definitive statement should be made due to uncertainties. In MCDA, thresholds have been introduced to prevent the overrating of very small indicator deviations, though "very small" is not exactly defined. Bouyssou [11] even found it of utmost importance to use thresholds when applying non-compensatory methods. For the determination of these thresholds, different approaches are available [12], based, for example, on the decision-makers' uncertainty about their preferences [13]. How reasonable thresholds can be defined in the context of LCSA is discussed in this paper. The focus here is on the uncertainty of impact categories in LCSA.

Some methodological aspects of LCSA are discussed beforehand in this paper, which are necessary for the determination of thresholds based on the applied indicators/impact categories. Furthermore, outranking in general and the chosen MCDA method is presented in more detail. Subsequently, our newly developed approach to derive indicator thresholds for LCSA is introduced based on Life Cycle Impact Assessment (LCIA).

To secure that a climate-friendly and cost-effective technology does not deteriorate other environmental impacts and social conditions, LCSA is applied to the industrial production of hydrogen with alkaline water electrolysis (AEL) in the European context. Up to now, only a few LCSAs for hydrogen have been conducted [14-16]. Here, the current situation of AEL is assessed. Three European countries (Austria, Germany and Spain) are compared as potential production locations based on earlier publications by the authors [17-19]. To find unambiguous statements about the preferential location in three selected Western European countries, we integrate MCDA in the interpretation phase of the LCSA without allowing compensation. The aim is to strengthen the validity of the conclusions obtained for the three quite similar systems. In particular, the question of which deviation of indicator results for two options is large enough to prefer one option to the other or if these indicator results have to be considered as indifferent is addressed. With the approach developed in this paper, LCSA practitioners will be able to integrate uncertainty in particular derived from the impact assessment methodology in a simple and practical manner.

\section{Methods}

The methodological goal is to derive thresholds for different impact assessment indicators to define indifferences and preferences of LCSA results that can be used in an outranking method for MCDA. To achieve this, first some methodological aspects are discussed that tackle, in particular, indicator selection and the definition of uncertainties. In addition, the chosen outranking method is presented with a focus on preferences and required thresholds. By quantifying the uncertainties for threshold definition, a specified 
threshold is assigned to each impact category so that indifferences and the preferences can be determined. To finalize this section the applied approach for weighting the different indicators is presented.

\subsection{Life Cycle Sustainability Assessment-Indicators and Uncertainties}

The LCSA is a partly standardized methodology [7] that consists of the three methods of Life Cycle Assessment (LCA), Life Cycle Costing (LCC) and social Life Cycle Assessment (S-LCA, and has been used for a wide range of studies [20]. The three methods originate from very different scientific disciplines and have different approaches in the LCIA phase. In particular, the S-LCA is a rather young method and varying strategies exist to assess social sustainability for a product or service [21]. For this study, the hot spot approach with the help of a database (Product Social Impact Life Cycle Assessment PSILCA [22]) has been chosen for S-LCA. Based on these framework conditions, indicator selection for LCSA is shortly introduced and different types of uncertainties are discussed.

\subsubsection{Indicators}

The LCSA indicator set comprises indicators from the LCA, LCC and S-LCA. The LCA is an established method to evaluate environmental impacts of technologies or products. The LCA indicator selection in this study is based on the International Reference Life Cycle Data System (ILCD) recommendations [23] and the more recent guidance from the UNEP/SETAC [24,25] on a midpoint level. The suggested method for the assessment of water (Swiss ecoscarcity), however, was substituted for the scarcity method AWARE, which is a more recent consensus in the field of water assessment [26]. The analysis is performed with the GaBi 7 software [27] using the ecoinvent [28] as well as the GaBi professional database [29]. LCC is an established approach in economics [30,31]. Here, the LCC indicators refer to a guide prepared by the European Investment Bank [32] and literature on economic assessment of energy technologies, e.g., [33]. As mentioned before, S-LCA is a relatively new field of research with little consensus on methodology and indicators. The PSILCA database 2.0 [22] as implemented in openLCA [34] applies one of several approaches which try to operationalize social assessment. The indicators are based on the S-LCA guidelines [21,35] and the accompanying methodological sheets [36]. In addition to the recommendations of the specific LCA, LCC and S-LCA methodologies, Sustainable Development Goals (SDGs) were used for the selection of meaningful indicators [34]. While the SDGs are defined on a country level and are often qualitative, the LCSA indicators are often on a technology level. In this indicator selection, double or even triple counting of indicators is prevented [15].

\subsubsection{Uncertainties}

The goal of an LCSA study is often the comparison between two or more different product systems. Uncertainty within the input data or assessment methods can result in a misleading assessment of the product systems. A discussion and quantification of uncertainties is therefore helpful to interpret the results. First, a distinction must be made between variability and uncertainty [37]. Variability comprises explicit practitioner choices with regard to time, e.g., setting the reference year to 2017 or 2020 or choosing between impact assessment methods with a timeframe of 20 or 100 years. Other types of variability address spatial differences, e.g., analyzed country, and differences between objects. Uncertainty, on the other hand includes everything we do not know, thus assumptions and simplifications have to be made. The sources for uncertainty are manifold. In Table 1, the different types of uncertainty are separated against each other, and each type is exemplified for the Life Cycle Inventory (LCI) phase and the LCIA phase, respectively. 
Table 1. Types of uncertainty in the Life Cycle Sustainability Assessment, based on [37].

\begin{tabular}{ccc}
\hline Type & Example Life Cycle Inventory & Example Life Cycle Impact Assessment \\
\hline Parameter uncertainty & Inaccurate data & Lifetimes of substances \\
\hline Model uncertainty & Assuming linearity & Assuming steady-state conditions \\
\hline Scenario uncertainty & Technology level & Characterization method (TAP500 or Accumulated Exceedance) \\
\hline Epistemological uncertainty & Ignorance & Ignorance \\
\hline Relevance uncertainty & - & Concentrating on indigenous rights with a product system \\
centered in Western Europe
\end{tabular}

Mostly addressed in LCA studies is parameter uncertainty of the LCI data $[37,38]$ using, e.g., a Monte Carlo analysis or the pedigree matrix approach, which is implemented in the ecoinvent database [28]. Benetto et al. [39] proposed to use these results from the Monte Carlo Analysis in the fuzzy multi-criteria method NAIADE. The group of Ren proposed in several papers $[40,41]$ to use interval numbers for indicator results combined with fuzzy methods. Less frequently, uncertainty in the LCIA is discussed. In their recent paper, Qin et al. [42] made an effort to also introduce the pedigree matrix to characterization factors in LCIA, but found the task "to create a different pedigree matrix for each impact category and each characterization model" [42] too complex for the estimated resources. Another way to integrate uncertainty of the LCIA into the MCDA was proposed by the Joint Research Centre (JRC) of the European Commission [43]. The main goal of this work was to introduce weighting factors for LCA indicators based on the opinion of the general public, LCA experts and LCIA development experts. However, this working group also included a factor into the weighting factors that accounts for the robustness of the LCIA method.

For LCC, the biggest issue is the uncertainty of the inventory, e.g., the discount rate or direct investment costs, rather than uncertainty of the impact assessment.

The types of uncertainty mainly applying for S-LCA are parameter and epistemological uncertainties. In our opinion, the largest factors for uncertain parameters here are missing detailed geographical resolution. Even when official data for a certain country or industrial sector is available, the number of unreported cases is high.

When integrating the LCSA indicator results by means of the MCDA, new uncertainty sources are added. In particular, the definition of weighting factors bears high uncertainties. Thus, several LC(S)A studies with MCDA tackled this challenge with different methods, e.g., $[40,43,44]$.

In this paper, we introduce a new approach for addressing uncertainty in the LCIA. The approach does not discuss the different types of uncertainty separately but combines parameter, model, scenario and epistemological uncertainty of the LCIA into one. Relevance uncertainty cannot be covered by this approach because it highly depends on the goal and scope definition of an LCSA and cannot be easily quantified. The same is true for mistakes.

\subsection{Outranking}

The most popular outranking methods are ELECTRE [44] and PROMETHEE [45,46]. In this publication, we focus on PROMETHEE because it guides users through the whole decision-making process.

PROMETHEE is a family of outranking methods developed by Brans and colleagues in the early 1980s [45,47]. Since then, several variations of this method have been developed to be guidance in more complex decision-making. This includes PROMETHEE I-VI and the visual interactive module GAIA (Geometrical Analysis for Interactive Aid) [48]. The most relevant variations are still PROMETHEE I and II, which will be used in this paper. 
The principle of PROMETHEE is based on a pairwise comparison of alternatives along each recognized criterion — understood as an indicator or an impact category—and can be described in five steps [46]:

1. Determination of deviations based on pairwise comparisons between different options.

2. Application of the preference function.

3. Calculation of the global preference index.

4. Calculation of positive and negative outranking flows for each alternative.

5. Net outranking flow for each alternative and complete ranking (only included in PROMETHEE II).

PROMETHEE I stops at step 4 and gives a partial ranking of the alternatives with the outranking flows $\Phi^{+}$and $\Phi^{-}$. The higher $\Phi^{+}$and the lower $\Phi^{-}$is, the better is the overall rank of the analyzed option. However, this can also lead to incomparabilities when $\Phi^{+}$and $\Phi^{-}$indicate different preferences. PROMETHEE II adds step 5 to derive a complete ranking of the alternatives (outranking flow $\Phi^{\text {net}}$ ) by calculating the difference between the two flows. This leads to a complete ranking under some degree of detail loss [49]. Thus, PROMETHEE I and II might come to different results. For a more detailed definition, consult the (Supplementary Material, which additionally includes a minimal example to explain the stepwise calculation. In general, $\Phi$ can be understood as the aggregated indicator or performance index as it is called in other MCDA methods. The actual outranking takes place in step 2. For a more elaborated outranking, preference functions are introduced, which are often deemed necessary due to very small differences between indicators and methodological uncertainties as discussed before. The preference functions translate the difference between the indicator results obtained by two alternatives into a preference degree ranging from zero to one. Strict preference (one), indifference (zero) and the zone of weak preferences (between zero and one) are denoted. In this way, the user can implement their opinion on what preference actually means. In PROMETHEE, six different preference functions for the criteria are proposed [45,49]. Based on the analyzed indicator (also known as criterion) different functions have their purpose regarding the level of uncertainty and the nature of the values, i.e., qualitative, discrete or continuous. The values of the LCSA practiced here are continuous, resulting in the suitable linear preference function shown in Figure 1 [50].

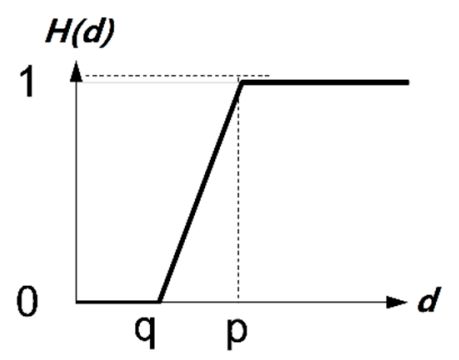

Figure 1. Preference function: Criterion with linear preference (weak preference zone: $q-p$ ) and indifference zone $(0-q)$ (q: indifference threshold; p: strict preference threshold).

The user has to define the parameters $q$ and $p$, which express absolute values. The indifference threshold q marks the value up to which two results are considered equal, and $p$ marks the value above which strict preference is given. Weak preferences exist between $\mathrm{q}$ and $\mathrm{p}$. For clearer understanding, this function is written as the following equation (Equation (1)):

$$
H_{k}(d)=\left\{\begin{aligned}
0, & \text { if } d \leq \mathrm{q}_{k} \\
\frac{d-\mathrm{q}_{k}}{\mathrm{p}_{k}-\mathrm{q}_{k},} & \text { if } \mathrm{q}_{k}<d \leq \mathrm{p}_{k} \\
1, & \text { if } d>\mathrm{p}_{k}
\end{aligned}\right.
$$

$d$ : indicator value;

$k$ : indicator index;

$H_{k}(d)$ : outranking value of indicator $k$ as a function of $d$. 
This function helps to deal with the uncertainties of the obtained indicator values [51], but the guidance how to derive good thresholds for this function is small. In general, these thresholds subsume different aspects of uncertainty and variability of input data and impact assessment methodology.

\subsection{Determination of Thresholds in Life Cycle Sustainability Assessment}

For every applied methodology in LCSA, e.g., LCA, uncertainty occurs in different areas. Ren et al. [52] performed an LCSA of different hydrogen production options and used PROMETHEE as the MCDA approach. They chose the Gaussian preference function with the average variance of the jth criterion, which can be considered as common thresholds without differing between different indicators. A similar approach is used by Rogers et al. [53] for their LCA study on drive trains for passenger vehicles accompanied with the outranking approach ELECTRE. In an LCSA study about tire life extension scenarios, do Carmo et al. [54] used PROMETHEE and defined thresholds by interviewing stakeholders, in this case, truck tire development experts. However, this requires that the stakeholders already know when indicator results can be considered as indifferent. For life cycle costs, this might be true; for human health indicators, this becomes questionable. In their most recent paper, Ren et al. [55] used the linear preference and indifference zone function when performing PROMETHEE for the LCSA of hydrogen production options. The thresholds are decided by decision makers, too. These values as well as the thresholds are part of the sensitivity analysis to reflect the subjectivity of these assumptions. To analyze uncertainty, rather than to perform MCDA, Mendoza Beltran et al. [56] applied modified Null Hypothesis Significance Testing on the LCA of different electric powertrains in passenger vehicles. They set a common 'difference threshold' equally for all analyzed indicators.

Common thresholds include several aspects of uncertainty based on, e.g., inventory and impact assessment. Instead of defining absolute thresholds $q$ and $p$ for each indicator individually, it is convenient to use the concept of relative thresholds $\mathrm{Q}$ and $\mathrm{P}$, enabling a flexible handling of thresholds. As a starting point, the relative default (index Def) thresholds, $\mathrm{Q}_{\text {Def }}$ and $\mathrm{P}_{\text {Def }}$, are defined in this study as 5 and $10 \%$ of the minimal indicator result, which is a practical approximation. This prevents options with relatively small differences to be ranked harshly. However, using these default values has a certain degree of arbitrariness [11] and LCSA practitioners know that for some impact categories uncertainties are higher. In general, it is difficult for decision makers to find reasonable thresholds [57].

Here, a new approach is introduced that determines indifference and preference thresholds based on the quantified uncertainty of only LCIA methods for each indicator as discussed in Section 2.1.2, representing a subset of uncertainty compared to what common thresholds ( $q, Q$ and $p, P)$ include. As these new thresholds only include a subset of the before discussed aspects subsumed in common thresholds, they are referenced as $\mathrm{q}^{\prime}$ and $\mathrm{p}^{\prime}$ from here on forward. Furthermore, with the indices Def and Spec (for specified), it is indicated if default thresholds, here 5 and $10 \%$ of the minimum values $\left(Q_{\text {Def }} / Q^{\prime}{ }_{\text {Def }}\right.$ and $\mathrm{P}_{\text {Def }} / \mathrm{P}^{\prime}$ Def $)$, are applied or if newly specified thresholds discussed in the following section $\left(\mathrm{Q}^{\prime}\right.$ Spec and $\left.\mathrm{P}^{\prime}{ }_{\text {Spec }}\right)$ are applied. That means that these specified thresholds exist only for the LCIA subset of what common thresholds include. This adds up to six different absolute thresholds ( $q_{\text {Def }}, \mathrm{p}_{\text {Def }}, \mathrm{q}_{\text {Def }}^{\prime}, \mathrm{p}_{\text {Def }}^{\prime}, \mathrm{q}_{\text {Spec }}^{\prime}, \mathrm{p}_{\text {Spec }}^{\prime}$ ) and a corresponding number of relative thresholds.

Each impact assessment method is assigned to one uncertainty class. As the three methods of LCSA - LCA, S-LCA and LCC — use different approaches for impact assessment, the methods are discussed separately in the following subsections. For LCA, several publications have been published regarding uncertainty $[37,38,58]$. Therefore, the approach is mainly developed based on the LCA and later adapted for the S-LCA. As a result, indicator specified thresholds can be applied in PROMETHEE. Other aspects, e.g., uncertainty of the inventory, are not considered. 


\subsubsection{Assignment of Uncertainty Classes in Life Cycle Assessment}

For LCA, JRC gives recommendations for midpoint and endpoint impact assessment methods by its ILCD [23]. The recommended impact assessment methods are rated against five criteria: (1) Completeness of scope, (2) Environmental relevance, (3) Scientific robustness and certainty, (4) Documentation, transparency and reproducibility, and (5) Applicability into three classes: I Recommended and satisfactory, II Recommended but in need of some improvements, and III Recommended but to be applied with caution [59]. In addition, already in 2009 Humbert et al. [60] assessed in a Monte Carlo simulation the uncertainty of impact assessment methods. For climate change and cumulative energy demand, they considered that "any difference lower than $10 \%$ is not ... significant". For particulate matter, acidification and eutrophication "the difference needs to be higher than $30 \%$ to be significant" and "For the toxicity categories, an order of magnitude (factor 10) difference is typically required for a difference to be significant" [60].

In this assessment, the two approaches are combined and the ILCD classification [59] from I to III is translated using the threshold levels of Humbert et al. [60]. Six uncertainty classes are defined by refining the classification of the ILCD. The whole numbers 1, 2 and 3 represent the classes I, II and III. Additionally, intermediate values from 1.5 to 3.5 are introduced to give more flexibility for other non-LCA indicators. Together with the uncertainty values from Humbert, this leads to the relative thresholds $\mathrm{Q}^{\prime}$ spec and $\mathrm{P}^{\prime}$ spec based on uncertainty classes (Table 2). As described at the beginning of this section, the percentage is related to the minimum value of the indicator results.

Table 2. Translation of uncertainty classifications into relative thresholds.

\begin{tabular}{ccc}
\hline Uncertainty Class & $\mathbf{Q}^{\prime}$ Spec & $\mathbf{P}^{\prime}$ Spec \\
\hline 1.0 & $10 \%$ & $20 \%$ \\
1.5 & $20 \%$ & $30 \%$ \\
2.0 & $30 \%$ & $40 \%$ \\
2.5 & $50 \%$ & $60 \%$ \\
3.0 & $70 \%$ & $80 \%$ \\
3.5 & $90 \%$ & $100 \%$ \\
\hline
\end{tabular}

For the different impact categories in LCA, this results in the definition of relative thresholds for weak preference (from $\mathrm{Q}^{\prime}$ Spec to $\mathrm{P}^{\prime}$ Spec) as listed in Table 3.

Table 3. Classification of LCA impact categories uncertainty according to [49] and definition of weak preference zones.

\begin{tabular}{ccc}
\hline Impact Category & Uncertainty Class & $\begin{array}{c}\text { Weak Preference Zone } \\
\mathbf{Q}^{\prime} \text { Spec }^{\prime} \mathbf{P}^{\prime} \text { Spec }\end{array}$ \\
\hline Climate change & 1 & $10-20 \%$ \\
Ozone depletion & 1 & $10-20 \%$ \\
Cumulated energy demand & 1 & $10-20 \%$ \\
Resource depletion, water & 2 & $30-40 \%$ \\
Resource depletion, mineral & 2 & $30-40 \%$ \\
Particulate matter/respiratory inorganics & 2 & $30-40 \%$ \\
Ionizing radiation, human health & 2 & $30-40 \%$ \\
Photochemical ozone formation & 2 & $30-40 \%$ \\
Acidification & 2 & $30-40 \%$ \\
Terrestrial eutrophication & 2 & $30-40 \%$ \\
Aquatic eutrophication & 2 & $30-40 \%$ \\
Marine eutrophication & 2 & $30-40 \%$ \\
Ecotoxicity, freshwater & 3 & $70-80 \%$ \\
Human toxicity, cancer & 3 & $70-80 \%$ \\
Human toxicity, non-cancer & 3 & $70-80 \%$ \\
\hline
\end{tabular}




\subsubsection{Assignment of Uncertainty Classes in Social Life Cycle Assessment}

For the characterization of social impacts in PSILCA, performance reference points are used (reference scale impact assessment RS-LCIA) [21,61]. Thus, it is not the characterization models for social LCIA are used for the uncertainty classification, but the input data of the performance reference points, e.g., women in the sectoral labour force in country xy in sector ab. Such data are provided, e.g., by the International Labour Organization [22].

Based on the uncertainties due to missing geographical resolution (Section 2.1.2) as well as the reliability and age of the data source for these reference points the assignment to the specific uncertainty classes is performed (Table 4). Most often, data availability for certain countries is an issue. In total, 189 countries are covered by the database. Some impact categories are downgraded due to high numbers of alleged undocumented cases, e.g., weekly hours of work per employee from 1.0 to 1.5 .

Table 4. Classification of PSILCA indicators uncertainty and definition of weak preference zones.

\begin{tabular}{|c|c|c|}
\hline Impact Category & Uncertainty Class & $\begin{array}{c}\text { Weak Preference Zone } \\
\mathbf{Q}^{\prime} \text { Spec }^{-P^{\prime} \text { Spec }}\end{array}$ \\
\hline Women in the sectoral labour force & 1.0 & $10-20 \%$ \\
\hline Life expectancy at birth & 1.0 & $10-20 \%$ \\
\hline Social security expenditures & 1.0 & $10-20 \%$ \\
\hline Unemployment & 1.0 & $10-20 \%$ \\
\hline Weekly hours of work per employee * & 1.5 & $20-30 \%$ \\
\hline Gender wage gap & 1.5 & $20-30 \%$ \\
\hline Net migration & 1.5 & $20-30 \%$ \\
\hline Health expenditure & 1.5 & $20-30 \%$ \\
\hline International migrant stock & 1.5 & $20-30 \%$ \\
\hline Fatal accidents & 1.5 & $20-30 \%$ \\
\hline Child labour, total * & 2.0 & $30-40 \%$ \\
\hline Public sector corruption * & 2.0 & $30-40 \%$ \\
\hline Trafficking in persons * & 2.0 & $30-40 \%$ \\
\hline Non-fatal accidents & 2.0 & $30-40 \%$ \\
\hline Certified environmental management system & 2.0 & $30-40 \%$ \\
\hline Indigenous rights & 2.0 & $30-40 \%$ \\
\hline Education & 2.0 & $30-40 \%$ \\
\hline Illiteracy, total & 2.0 & $30-40 \%$ \\
\hline Youth illiteracy, total & 2.0 & $30-40 \%$ \\
\hline Fair salary & 2.0 & $30-40 \%$ \\
\hline Association and bargaining rights & 2.0 & $30-40 \%$ \\
\hline Trade union density & 2.0 & $30-40 \%$ \\
\hline Social responsibility along the supply chain & 2.5 & $50-60 \%$ \\
\hline Drinking water coverage & 2.5 & $50-60 \%$ \\
\hline Sanitation coverage & 2.5 & $50-60 \%$ \\
\hline International migrant workers (in the sector/site) * & 3.0 & $70-80 \%$ \\
\hline Active involvement of enterprises in corruption and bribery * & 3.0 & $70-80 \%$ \\
\hline Frequency of forced labour * & 3.0 & $70-80 \%$ \\
\hline Safety measures & 3.0 & $70-80 \%$ \\
\hline Workers affected by natural disasters & 3.0 & $70-80 \%$ \\
\hline Violations of employment laws and regulations * & 3.5 & $90-100 \%$ \\
\hline Goods produced by forced labour* & 3.5 & $90-100 \%$ \\
\hline Anti-competitive behavior or violation of anti-trust and monopoly legislation * & 3.5 & $90-100 \%$ \\
\hline Presence of business practices deceptive or unfair to consumers * & 3.5 & $90-100 \%$ \\
\hline
\end{tabular}

* Downgraded indicators due to high numbers of alleged undocumented cases.

\subsubsection{Assignment of Uncertainty Classes in Life Cycle Costing}

For LCC, no impact assessment methodology is used. As no uncertainties are considered (Section 2.1.2), no preference functions are necessary and for each indicator a strict preference can be determined for the discussed options.

\subsection{Weighting of Indicators}

For deriving weighting factors for the LCSA indicators, several MCDA approaches are available. For example, for LCA, subjective weighting factors have been developed based on the opinion of the general public, LCA experts and LCIA development experts [43]. However, these weighting factors do not include the other two LCSA dimensions and can 
thus not be applied. The applications of other weighting approaches also imply valuebased choices, e.g., [62-64]. To keep weighting simple and to focus on thresholds in this study, a two-stage equal-weighting approach is used-being fully aware that there are many other reasonable approaches available. That means that on the first step (LCA vs. S-LCA vs. LCC), each sustainability dimension is equally important (weighting factor $\mathrm{w}_{\text {Sus }}=1 / 3$ ). Within each dimension (second step), each indicator receives the same weight $\left(\mathrm{w}_{\mathrm{LCC}}=1 / 4, \mathrm{w}_{\mathrm{LCA}}=1 / 15, \mathrm{w}_{\mathrm{S}-\mathrm{LCA}}=1 / 26\right)$. The absolute weighting factor of each indicator is derived from the multiplication of the individual weighting factors $\left(w_{\text {Sus }} \times w_{i}\right)$. This implies low indicator weight in case of a high number of indicators within a dimension. The method explicitly accepts that indicators from different dimensions have different weights in case the number of indicators per dimension is different. Vice versa, requiring indicators having same weights goes along with different weights for dimensions if there are different numbers of indicators per dimension.

\section{Case Study of Industrial Hydrogen Production by Alkaline Water Electrolysis}

The object of this LCSA is the hydrogen production by an advanced AEL in three European countries. First, a description of the technical system is provided, followed by a short presentation and discussion of the indicator results, i.e., the LCA, LCC and S-LCA. In these results, uncertainty is not considered at this point and will be discussed in the results for PROMETHEE (Section 4).

\subsection{System Description}

It is assumed that the mature technology of AEL is manufactured in Switzerland using technical input data from a local AEL supplier. The assembled electrolyzer is then transported to operation sites in either Germany, Austria or Spain. All three countries represent advanced Western European countries but differ with respect to important parameters, such as electricity supply, integration into international trade or social framework. However, other parameters might be quite similar, which emphasizes the use of indifference and preference thresholds to distinguish differences. Figure 2 outlines the components considered in the assessments from cradle-to-gate.

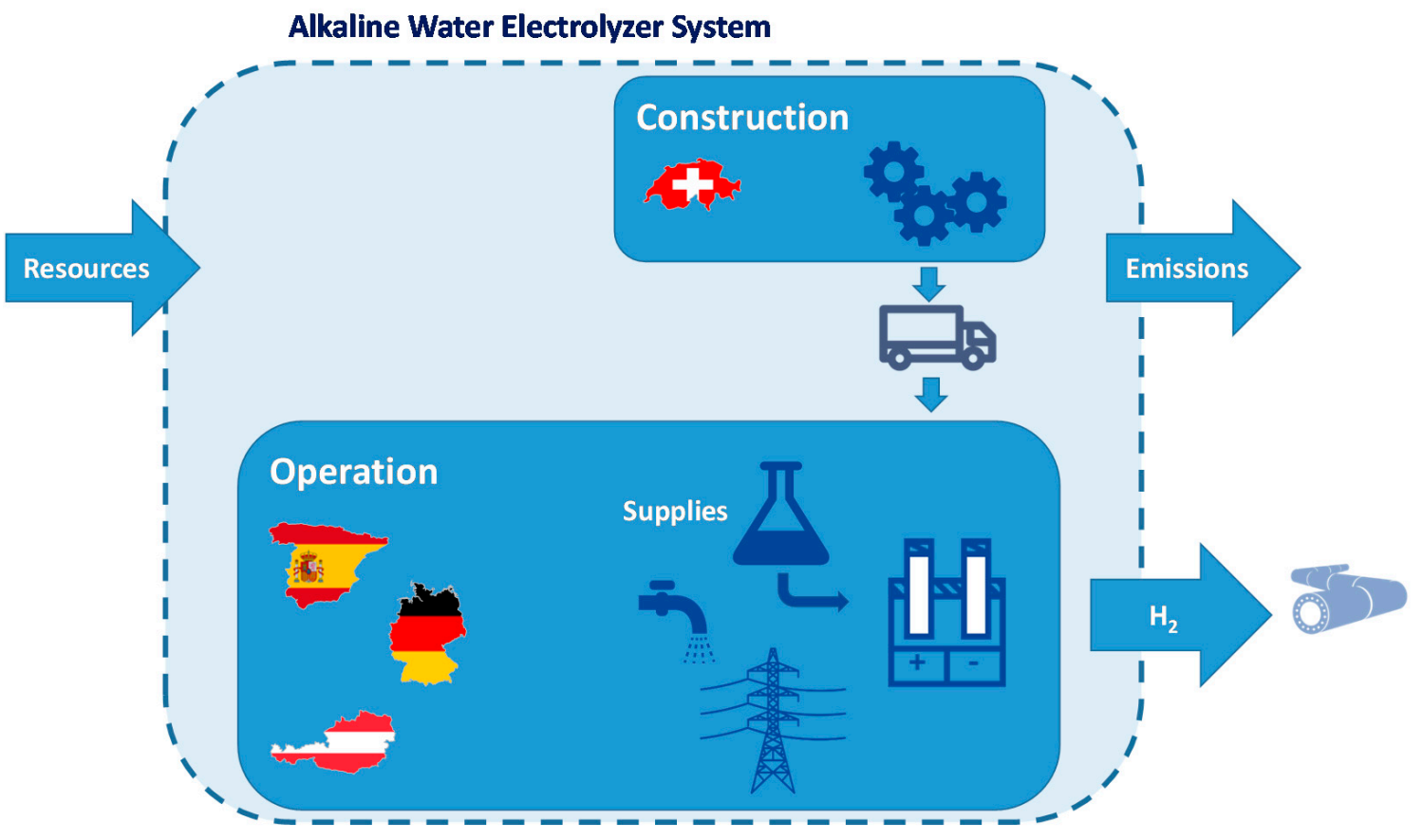

Figure 2. Outline of the $6 \mathrm{MW}$ alkaline water electrolyzer system. 
The core element is the construction and operation of a pressurized $6 \mathrm{MW}$ AEL, which contains four cell stacks consisting of 139 cells each within a stack framework embedded in the balance of plant (BOP). Electrolysis cells consist of a membrane, electrodes, a cell frame and a gasket. The BOP comprises tanks, heat exchangers, pumps, power electronics/inverter and a potassium hydroxide filter. A detailed elaboration of the structure and materials used for the AEL unit as well as an extensive description of the system boundaries are given in Koj et al. [17].

The technical lifetime of the unit is expected to be 20 years, with a replacement of cell stacks necessary after ten years. Assuming a yearly operation time of $8300 \mathrm{~h} / \mathrm{year}$, the hydrogen output of the $6 \mathrm{MW}$ AEL unit $\left(118.25 \mathrm{~kg} \mathrm{H}_{2} / \mathrm{h}\right)$ has a production rate of $980 \mathrm{t} / \mathrm{a}$ (based on scaled-up data for a commercial AEL unit from the EU R\&D project ELYGRID [65]). In addition to large amounts of electricity, further operation inputs include de-ionized water, potassium hydroxide solution $(\mathrm{KOH})$, process steam and nitrogen. While electricity, de-ionized water and $\mathrm{KOH}$ are relevant for the electrolysis process constantly, process steam and nitrogen are required for the run-up phases only.

The functional unit is the production of $1 \mathrm{~kg}$ of hydrogen at $33 \mathrm{bar}$ and $40^{\circ} \mathrm{C}$. Hydrogen compression, storage, transport and further use are not considered. Due to the lack of data availability, the end-of-life treatment was not integrated. The utilization/selling of the by-product oxygen is not taken into account, as large-scale deployment of electrolysis capacities may go along with market saturation for oxygen and strongly decrease prices [66]. Consequently, no allocation is necessary.

The specific material and energy inputs of the $6 \mathrm{MW}$ AEL corresponding with the production of $1 \mathrm{~kg}$ of hydrogen are summarized in Table 5. The table additionally includes the industrial sectors used for these inputs in the modelling with of the S-LCA with PSILCA.

Table 5. Specific material and energy inputs per kg of hydrogen produced [65] and their respective industrial sectors (input PSILCA) [19].

\begin{tabular}{|c|c|c|c|c|c|}
\hline & Unit Per kg $\mathrm{H}_{2}$ & & DE & AT & ES \\
\hline Electricity & $\mathrm{kWh}_{\mathrm{el}}$ & 53.9 & Electricity and district heat & $\begin{array}{l}\text { Electrical energy, gas, steam and } \\
\text { hot water }\end{array}$ & $\begin{array}{l}\text { Production and distribution of } \\
\text { electricity }\end{array}$ \\
\hline Water, de-ionized & $\mathrm{kg}$ & 10.11 & Water supply & $\begin{array}{l}\text { Collection, purification and } \\
\text { distribution of water }\end{array}$ & $\begin{array}{l}\text { Collection, purification and } \\
\text { distribution of water }\end{array}$ \\
\hline $\mathrm{KOH}$ solution & $\mathrm{mg}$ & 275 & Manufacture of chemical products & $\begin{array}{l}\text { Chemicals, chemical products } \\
\text { and man-made fibres }\end{array}$ & Basic chemical products \\
\hline $\begin{array}{l}\text { Process steam } \\
\text { (Natural gas and } \\
\text { heating oil for } \\
\text { steam from water) }\end{array}$ & $\mathrm{g}$ & 38 & $\begin{array}{l}\text { Gas supply/Coal, coke and } \\
\text { petroleum products, nuclear } \\
\text { fuels/Water supply }\end{array}$ & $\begin{array}{l}\text { Electrical energy, gas, steam and } \\
\text { hot water/Coke, refined } \\
\text { petroleum products and nuclear } \\
\text { fuel/Collection, purification and } \\
\text { distribution of water }\end{array}$ & $\begin{array}{l}\text { Manufacture and distribution of } \\
\text { gas/Coke, refined petroleum } \\
\text { products and nuclear } \\
\text { fuel/Collection, purification and } \\
\text { distribution of water }\end{array}$ \\
\hline Nitrogen & $\mathrm{mg}$ & 71.15 & Manufacture of chemical products & $\begin{array}{l}\text { Chemicals, chemical products } \\
\text { and man-made fibres }\end{array}$ & Basic chemical products \\
\hline
\end{tabular}

While the technology parameters are identical for all countries under consideration, the supply of inputs is country-specific. The electricity supply reflects the national gross production mixes (see also [17]). For investment as well as operation and maintenance, costs correspond to the country specific markets and regulatory conditions.

\subsection{Indicator Results}

The LCSA of the hydrogen production is based on three different already existing assessments: the LCA [17], LCC [18] and S-LCA [19]. The previous LCA [17] compared the environmental effects considering nine impact categories. In a subsequent assessment, a further six categories were added [15]. The results emphasize the almost exclusive dependence of most environmental effects on the operation phase caused by the sitespecific electricity mix. For most impacts, its share amounts to $80 \%$ in the case of Austria and even $90 \%$ in the cases of Spain and Germany. Austria shows the lowest environmental impacts in 13 out of 15 categories. Only for 'Eutrophication, freshwater', mainly caused by phosphorous compounds from bioenergy in the electricity mix, does Austria perform 
the worst. For 'Human toxicity', specifically concerning cancer effects, Spain shows lower impacts (Table 6).

Table 6. LCSA indicator results, based on [15].

\begin{tabular}{|c|c|c|c|c|}
\hline Indicator & Unit & DE & AT & ES \\
\hline \multicolumn{5}{|l|}{ LCA } \\
\hline Acidification & mMole $\mathrm{H}^{+}$eq. & 44.5 & 21.6 & 50.3 \\
\hline Climate change & $\mathrm{kg} \mathrm{CO}_{2}$ eq. & 29.8 & 10.2 & 16.2 \\
\hline Cumulative energy demand & MJ & 534 & 341 & 513 \\
\hline Ecotoxicity, freshwater & CTUe & 5.59 & 3.31 & 3.71 \\
\hline Eutrophication, marine & g N eq. & 11.2 & 7.31 & 11.6 \\
\hline Eutrophication, freshwater & mg P eq. & 128 & 133 & 93 \\
\hline Eutrophication, terrestrial & mMole N eq. & 116 & 65 & 121 \\
\hline Human toxicity cancer & $\mathrm{nCTU}_{\mathrm{h}}$ & 37.5 & 14.8 & 27.1 \\
\hline Human toxicity non-cancer & $\mathrm{nCTU}_{\mathrm{h}}$ & 977 & 507 & 434 \\
\hline Ionizing radiation & Bq U235 eq. & 2760 & 32 & 3200 \\
\hline Ozone depletion & ng CFC-11 eq. & 63.2 & 43.8 & 50.3 \\
\hline Particulate matter & $\mathrm{mg} \mathrm{PM}_{2.5}$ eq. & 2000 & 870 & 246 \\
\hline Photochemical ozone creation & g NMVOC & 30.0 & 16.4 & 33.0 \\
\hline Resource depletion-Abiotic resources & mg Sb eq. & 129 & 388 & 938 \\
\hline Resource depletion-Water & $\mathrm{m}^{3}$ world eq. & 23.6 & 23.9 & 43.9 \\
\hline \multicolumn{5}{|l|}{ LCC } \\
\hline Levelized cost of hydrogen & $€_{2015} / \mathrm{kg} \mathrm{H}_{2}$ & 3.64 & 4.22 & 4.31 \\
\hline Profitability index * & - & -6.38 & -7.45 & -7.74 \\
\hline Net present value * & $\mathrm{m}_{2015} / \mathrm{kg} \mathrm{H} 2$ & -50.1 & -58.1 & -59.4 \\
\hline Marginal cost & $€_{2015} / \mathrm{kg} \mathrm{H}_{2}$ & 3.72 & 4.52 & 4.73 \\
\hline \multicolumn{5}{|l|}{ S-LCA } \\
\hline $\begin{array}{l}\text { Active involvement of enterprises in corruption } \\
\text { and bribery }\end{array}$ & Med. Rh & 2.15 & 2.94 & 4.55 \\
\hline Association and bargaining rights & Med. $\mathrm{Rh}$ & 6.54 & 16.48 & 1.81 \\
\hline Certified environmental management system & Med. Rh & 19.41 & 37.19 & 20.47 \\
\hline Child labour, total & Med. Rh & 0.98 & 1.08 & 0.60 \\
\hline Drinking water coverage & Med. Rh & 2.60 & 2.90 & 1.65 \\
\hline Education & Med. $\mathrm{Rh}$ & 3.01 & 2.32 & 4.56 \\
\hline Fair salary & Med. Rh & 5.46 & 7.73 & 2.30 \\
\hline Fatal accidents & Med. Rh & 0.40 & 0.55 & 0.26 \\
\hline Frequency of forced labour & Med. Rh & 0.46 & 0.57 & 0.16 \\
\hline Gender wage gap & Med. Rh & 5.47 & 31.94 & 7.96 \\
\hline Goods produced by forced labour & Med. Rh & 0.30 & 0.29 & 0.22 \\
\hline Health expenditure & Med. Rh & 6.07 & 6.24 & 3.59 \\
\hline Illiteracy, total & Med. Rh & 4.45 & 4.43 & 2.21 \\
\hline Indigenous rights & Med. Rh & 1.44 & 1.79 & 0.78 \\
\hline Non-fatal accidents & Med. Rh & 4.03 & 13.82 & 27.12 \\
\hline Public sector corruption & Med. Rh & 15.99 & 16.85 & 12.68 \\
\hline Safety measures & Med. Rh & 4.89 & 5.71 & 5.15 \\
\hline Sanitation coverage & Med. Rh & 13.89 & 14.17 & 8.15 \\
\hline Social security expenditures & Med. Rh & 5.79 & 5.72 & 2.62 \\
\hline Trade union density & Med. Rh & 25.75 & 18.46 & 43.89 \\
\hline Trafficking in persons & Med. Rh & 2.30 & 2.81 & 1.34 \\
\hline Unemployment & Med. Rh & 0.81 & 0.77 & 37.43 \\
\hline Violations of employment laws and regulations & Med. Rh & 1.93 & 3.22 & 3.04 \\
\hline Weekly hours of work per employee & Med. Rh & 0.26 & 0.48 & 0.45 \\
\hline Women in the sectoral labour force & Med. Rh & 1.85 & 1.93 & 3.93 \\
\hline Youth illiteracy, total & Med. Rh & 0.75 & 0.81 & 0.45 \\
\hline
\end{tabular}

CTU: Comparative toxic unit; Med. Rh: medium risk hours; * Only costs and no revenues are considered, leading to negative values.

Considering 'Resource depletion-water', hydrogen production in Spain has the highest impact due to its water scarcity. However, the highest 'Resource depletion-Water' impact was the electrolyzer production, which is the same for all three process chains. It is 
almost exclusively caused by the upstream chain of nickel, which is crucial for the anode, cathode and cell frame. In addition, 'Ozone depletion' is almost completely dominated by nickel and the polytetrafluoroethylene used for cell manufacturing. For all other impact categories, construction of system components and the replacement of cell stacks have minor contributions.

Overall, from the environmental perspective, hydrogen production in Austria is by far the best option. Between Spain and Germany, the ranking is almost even, with Germany scoring the worst in eight categories and the best in one and Spain scoring the worst in seven and the best twice.

For the evaluation of the economic impacts of the system $[15,18]$ country specific investment and operational costs (O\&M), labor cost and, in particular, electricity costs were taken into account. The electricity costs differ widely in the countries considered due to national regulations for electricity generation and the transformation towards sustainable electricity systems with a high penetration of renewable and carbon-free energy sources. Again, the results are dominated by the need of electricity. In contrast to the environmental impacts, the German hydrogen production performs best in all financial metrics, due to a beneficial regulatory status of energy-intensive industries within the financial support of renewable energy sources. Although investment cost is slightly lower and labor cost is significantly lower in Spain, the difference cannot outweigh the higher electricity cost compared to Germany. Austria is always between Germany and Spain.

The S-LCA [15] complements the environmental and economic assessment. In Werker et al. [19], a deeper analysis of 5 out of 26 indicators was conducted to address the working conditions under which industrial hydrogen production takes place in the EU. The results showed that hydrogen production in Austria entails the highest risks in four out of five categories, followed by Spain and Germany. It also showed that with respect to 'Trade union density' and 'Fair salary', other upstream locations, such as India and China, negatively affect the Austrian and German process chain. 'Gender wage gap' and 'Weekly hours of work per employee' are mainly caused within the countries Austria and Spain. Considering the remaining 21 social indicators, Austria scores the worst 15 times, while Spain has the lowest risks in 13 impact categories [15]. Overall, the risks associated stem mainly from the water $(\varnothing 60 \%)$ and electricity (ø 40\%) sector as well as their upstream chains. Other sectors only exert marginal impact. All indicator results are summarized in Table 6.

Summarizing the results of the three dimensions of sustainability, there is no clear winner. While Austria most often has the lowest environmental impacts, Germany has the lowest costs and Spain most often has the lowest social risks. This emphasizes the use of the MCDA to combine the different outcomes. The question of uncertainties and thresholds comes on top.

\section{PROMETHEE for Integrating LCSA of Industrial Hydrogen Production}

As each type of analysis, i.e., LCA, LCC, S-LCA, leads to a different preferred location for hydrogen production, an outranking becomes necessary. In order to make a decision on the best location for sustainable hydrogen production, PROMETHEE is applied. As the previous studies also indicated that several impacts are in a quite similar range, the application of thresholds seems reasonable. Here, first the results of PROMETHEE with relative common default thresholds of $Q_{D e f}=5 \%$ and $P_{D e f}=10 \%$ of the minimal indicator result are presented. In a second section, the influence of specifying the thresholds ( $q^{\prime}$ spec, $\mathrm{p}^{\prime}$ Spec) to LCIA methods is discussed.

\subsection{PROMETHEE Results with Common Default Thresholds for Uncertainty in General}

Using the common threshold concept with default values, quantifying the absolute thresholds leads to individual absolute $q_{\text {Def }}$ and $p_{\text {Def }}$ values for each indicator. These absolute thresholds are listed in Table 7 for the discussed default approach. For a better understanding of the procedure in PROMETHEE as well as the deviations between two options, i.e., pairwise country comparisons, based on the results presented in Table 6 are 
listed in Table 7. If indicator values result in indifference for two countries, this is indicated with italic writing of the indicator; italic writing of the deviation shows which country pairing has indifferent results for this indicator.

Table 7. Absolute $p_{\text {Def }}$ and $q_{\text {Def }}$ thresholds for hydrogen production, with default approach and deviations between indicator results (italics: indifference between two options).

\begin{tabular}{|c|c|c|c|c|c|c|}
\hline \multirow{2}{*}{ Indicator } & \multirow{2}{*}{ Unit } & \multirow{2}{*}{$\mathrm{q}_{\text {Def }}$} & \multirow{2}{*}{$\mathrm{p}_{\text {Def }}$} & \multicolumn{3}{|c|}{ Deviation } \\
\hline & & & & DE-AT & DE-ES & AT-ES \\
\hline \multicolumn{7}{|l|}{ LCA } \\
\hline Acidification & mMole $\mathrm{H}^{+}$eq. & 1.08 & 2.16 & 22.90 & 5.8 & 28.70 \\
\hline Climate change & kg CO 2 eq. & 0.51 & 1.02 & 19.60 & 13.60 & 6.00 \\
\hline Cumulative energy demand & MJ & 17.1 & 34.1 & 193.0 & 21.0 & 172.0 \\
\hline Ecosystem toxicity, freshwater & CTUe & 0.17 & 0.33 & 2.28 & 1.88 & 0.40 \\
\hline Eutrophication, marine & g N eq. & 0.36 & 0.73 & 3.89 & 0.40 & 4.29 \\
\hline Eutrophication, freshwater & mg P eq. & 4.66 & 9.32 & 5.00 & 34.80 & 39.80 \\
\hline Eutrophication, terrestrial & mMole N eq. & 3.25 & 6.5 & 51.00 & 5.00 & 56.00 \\
\hline Human toxicity cancer & $\mathrm{nCTU}_{\mathrm{h}}$ & 0.74 & 1.48 & 22.70 & 10.40 & 12.3 \\
\hline Human toxicity non-cancer & $\mathrm{nCTU}_{\mathrm{h}}$ & 21.7 & 43.4 & 470 & 543 & 73.0 \\
\hline Ionizing radiation & mBq U235 eq. & 1.64 & 3.28 & 2727 & 440 & 3170 \\
\hline Ozone depletion & ng CFC-11 eq. & 2.19 & 4.38 & 19.40 & 12.90 & 6.50 \\
\hline Particulate matter & $\mathrm{mg} \mathrm{PM}_{2.5}$ eq. & 43.5 & 87.0 & 1130 & 460 & 1590 \\
\hline Photochemical ozone creation & g NMVOC & 0.82 & 1.64 & 13.60 & 3.00 & 16.60 \\
\hline Resource depletion-Abiotic resources & mg Sb eq. & 1.94 & 3.88 & 90.2 & 35.2 & 55.0 \\
\hline Resource depletion-Water & $\mathrm{m}^{3}$ world eq. & 1.18 & 2.36 & 0.28 & 20.30 & 20.02 \\
\hline \multicolumn{7}{|l|}{ LCC } \\
\hline Levelized cost of hydrogen & $€_{2015} / \mathrm{kg} \mathrm{H} 2$ & 0.182 & 0.364 & 0.580 & 0.670 & 0.090 \\
\hline Net present value & $\mathrm{m}_{2015} / \mathrm{kg} \mathrm{H} 2$ & $2.97 *$ & $5.94 *$ & $8.00 *$ & $9.30 *$ & $1.30 *$ \\
\hline Profitability index & -8 & $0.387 *$ & $0.774 *$ & $1.070 *$ & $1.360 *$ & $0.290 *$ \\
\hline Marginal cost & $€_{2015} / \mathrm{kg} \mathrm{H}_{2}$ & 0.186 & 0.372 & 0.800 & 1.010 & 0.210 \\
\hline \multicolumn{7}{|l|}{ S-LCA } \\
\hline $\begin{array}{l}\text { Active involvement of enterprises in corruption } \\
\text { and bribery }\end{array}$ & Med. Rh & 0.11 & 0.21 & 0.80 & 2.40 & 1.61 \\
\hline Association and bargaining rights & Med. $\mathrm{Rh}$ & 0.09 & 0.18 & 9.94 & 4.73 & 14.67 \\
\hline Certified environmental management system & Med. Rh & 0.97 & 1.94 & 17.77 & 1.05 & 16.72 \\
\hline Child labour & Med. Rh & 0.03 & 0.06 & 0.10 & 0.38 & 0.48 \\
\hline Drinking water coverage & Med. Rh & 0.08 & 0.17 & 0.30 & 0.95 & 1.24 \\
\hline Education & Med. Rh & 0.12 & 0.23 & 0.69 & 1.55 & 2.24 \\
\hline Fair salary & Med. Rh & 0.12 & 0.23 & 2.27 & 3.16 & 5.43 \\
\hline Fatal accidents & Med. Rh & 0.01 & 0.03 & 0.15 & 0.14 & 0.29 \\
\hline Frequency of forced labour & Med. Rh & 0.01 & 0.02 & 0.11 & 0.29 & 0.41 \\
\hline Gender wage gap & Med. Rh & 0.27 & 0.55 & 26.47 & 2.49 & 23.98 \\
\hline Goods produced by forced labour & Med. Rh & 0.011 & 0.022 & 0.008 & 0.080 & 0.072 \\
\hline Health expenditure & Med. Rh & 0.18 & 0.36 & 0.17 & 2.47 & 2.65 \\
\hline Illiteracy, total & Med. Rh & 0.11 & 0.22 & 0.02 & 2.25 & 2.23 \\
\hline Indigenous rights & Med. Rh & 0.04 & 0.08 & 0.35 & 0.66 & 1.02 \\
\hline Non-fatal accidents & Med. Rh & 0.20 & 0.40 & 9.78 & 23.09 & 13.31 \\
\hline Public sector corruption & Med. Rh & 0.63 & 1.27 & 0.87 & 3.31 & 4.17 \\
\hline Safety measures & Med. $\mathrm{Rh}$ & 0.24 & 0.49 & 0.82 & 0.26 & 0.57 \\
\hline Sanitation coverage & Med. Rh & 0.41 & 0.82 & 0.28 & 5.74 & 6.02 \\
\hline Social security expenditures & Med. $\mathrm{Rh}$ & 0.13 & 0.26 & 0.07 & 3.17 & 3.10 \\
\hline Trade union density & Med. Rh & 0.92 & 1.85 & 7.29 & 18.14 & 25.43 \\
\hline Trafficking in persons & Med. Rh & 0.07 & 0.13 & 0.52 & 0.96 & 1.48 \\
\hline Unemployment & Med. Rh & 0.04 & 0.08 & 0.04 & 36.62 & 36.66 \\
\hline Violations of employment laws and regulations & Med. Rh & 0.10 & 0.19 & 1.29 & 1.11 & 0.18 \\
\hline Weekly hours of work per employee & Med. Rh & 0.013 & 0.026 & 0.212 & 0.181 & 0.030 \\
\hline Women in the sectoral labour force & Med. Rh & 0.09 & 0.19 & 0.07 & 2.07 & 2.00 \\
\hline Youth illiteracy, total & Med. Rh & 0.02 & 0.04 & 0.06 & 0.30 & 0.36 \\
\hline
\end{tabular}

CTU: Comparative toxic units; Med. rh: medium risk hours; ${ }^{*}$ For indicators with negative indicator results, here, absolute values are taken for further calculations. 
The different dimensions of the LCSA are unequally affected by the application of thresholds. From the 15 LCA indicators, only 'Resource depletion-Water' shows results that can be considered equal between Germany and Austria. For all other LCA indicators, a clear distinction can be made which option to prefer. Weak preference is represented three times between Germany and Spain ('Cumulative energy demand', 'Eutrophication, marine' and 'Eutrophication, terrestrial') and once for 'Eutrophication, freshwater' between Germany and Austria.

The matter is different for LCC, as three out of four indicators of indifference between Austria and Spain can be identified, and for the fourth indicator, only a weak preference between those countries applies. Thus, a more detailed analysis is advised. For example, in Austria the connection to the grid level has a strong influence on the electricity prices (7.64 to $10.13 €_{2015} \mathrm{c} / \mathrm{kWh}$ ) [18] and prices for electricity for industrial customers rose by $23 \%$ from 2017 to 2020 (excluding VAT, deductible taxes and other levies) [67].

Six out of 26 S-LCA indicators show indifference between two options, which is always between Germany and Austria. Additionally, there were five times when only a weak preference between the indicator results applied. However, this is evenly distributed between the country parings and never are all three options of one indicator affected by weak preference.

These absolute thresholds are used to calculate the PROMETHEE I and II results for the selection of location for industrial hydrogen production in Europe. In Figure 3, the corresponding outranking flows are shown in a bar chart.

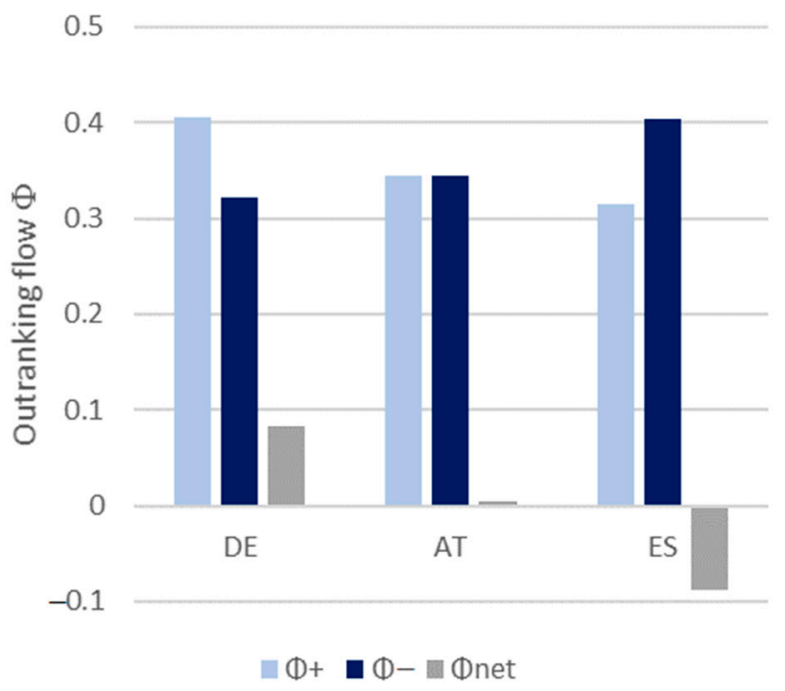

Figure 3. Outranking results using default thresholds for selecting the more sustainable location for hydrogen production; PROMETHEE I: $\Phi^{+}$and $\Phi^{-}$, PROMETHEE II: $\Phi_{\text {net }}$ (DE: Germany, AT: Austria, ES: Spain).

The two outranking flows of PROMETHEE I $\left(\Phi^{+}\right.$and $\left.\Phi^{-}\right)$as well as the outranking flow of PROMETHEE II ( $\left.\Phi_{\text {net }}\right)$ show the same tendency in their results. Hydrogen production in Germany is more sustainable than in Austria or Spain and production in Spain is in the selection of these countries always the least sustainable option. Thus, no incomparabilities occur and PROMETHEE I and II come to the same conclusions.

\subsection{PROMETHEE Results with Specified Thresholds Based on Uncertainty in Life Cycle Impact Assessment}

In the second analysis, the thresholds do not address uncertainty in general but are specified to the LCIA. As presented in Section 2.3 specified absolute thresholds ( $q_{\text {'Spec }}^{\text {Spe }}$ and $\mathrm{p}^{\prime}$ Spec) for each indicator are derived based on the different uncertainties of their characterization models and reference values. These specified thresholds are compared with default thresholds $\left(\mathrm{Q}^{\prime}{ }_{\text {Def }}=5 \%\right.$ and $\mathrm{P}^{\prime}{ }_{\text {Def }}=10 \%$ again as a practical approximation). 
In Table 8, relative thresholds $\left(\mathrm{Q}^{\prime}\right.$ and $\left.\mathrm{P}^{\prime}\right)$ are converted to absolute numbers $\left(\mathrm{q}^{\prime}\right.$ and $\left.\mathrm{p}^{\prime}\right)$ based on the hydrogen production case study. It has to be stressed that even though here the same default values are taken as in Table 7 they only represent uncertainty due to the impact assessment. The LCC is not listed here because, as described above, it does not use an impact characterization model in the life cycle thinking sense. The LCC indicators are included in the PROMETHEE analysis without thresholds. Similar to Table 7, italic writing of an indicator indicates indifference based on the specified thresholds for two options. Moreover, bold writing indicates indifference for all three options. For deviations between the different hydrogen production options refer to Table 7.

Table 8. Absolute $\mathrm{p}^{\prime}$ and $\mathrm{q}^{\prime}$ thresholds for hydrogen production, with default and indicator specified values addressing uncertainty in the impact assessment (bold: indifference between all options, italic: indifference between two options-for indicator specified thresholds).

\begin{tabular}{|c|c|c|c|c|c|}
\hline \multirow[b]{2}{*}{ Indicator } & \multirow[b]{2}{*}{ Unit } & \multicolumn{2}{|c|}{ Default Thresholds } & \multicolumn{2}{|c|}{ Indicator Specified Thresholds } \\
\hline & & $\mathbf{q}_{\text {Def }}^{\prime}$ & $\mathbf{p}_{\text {Def }}^{\prime}$ & $\mathbf{q}^{\prime}$ Spec & $\mathbf{p}_{\text {Spec }}^{\prime}$ \\
\hline LCA & & & & & \\
\hline Acidification & mMole $\mathrm{H}^{+}$eq. & 1.08 & 2.16 & 6.48 & 8.64 \\
\hline Climate change & $\mathrm{kg} \mathrm{CO} 2$ eq. & 0.51 & 1.02 & 1.02 & 2.04 \\
\hline Cumulative energy demand & $\mathrm{MJ}$ & 17.1 & 34.1 & 34.1 & 68.2 \\
\hline Ecosystem toxicity, freshwater & CTUe & 0.17 & 0.33 & 2.32 & 2.65 \\
\hline Eutrophication, marine & g N eq. & 0.36 & 0.73 & 2.19 & 2.92 \\
\hline Eutrophication, freshwater & mg P eq. & 4.66 & 9.32 & 28.0 & 37.3 \\
\hline Eutrophication, terrestrial & mMole N eq. & 3.25 & 6.5 & 19.5 & 26.0 \\
\hline Human toxicity cancer & $\mathrm{nCTU}_{\mathrm{h}}$ & 0.74 & 1.48 & 10.4 & 11.8 \\
\hline Human toxicity non-cancer & $\mathrm{nCTU}_{\mathrm{h}}$ & 21.7 & 43.4 & 304 & 347 \\
\hline Ionizing radiation & mBq U235 eq. & 1.64 & 3.28 & 9.8 & 13.1 \\
\hline Ozone depletion & ng CFC-11 eq. & 2.19 & 4.38 & 4.38 & 8.76 \\
\hline Particulate matter & mg $\mathrm{PM}_{2.5}$ eq. & 43.5 & 87.0 & 261 & 348 \\
\hline Photochemical ozone creation & g NMVOC & 0.82 & 1.64 & 4.92 & 6.56 \\
\hline Resource depletion-Abiotic resources & mg Sb eq. & 1.94 & 3.88 & 11.6 & 15.5 \\
\hline Resource depletion-Water & $\mathrm{m}^{3}$ world eq. & 1.18 & 2.36 & 7.09 & 9.46 \\
\hline \multicolumn{6}{|l|}{ S-LCA } \\
\hline Active involvement of enterprises in corruption and bribery & Med. $\mathrm{Rh}$ & 0.11 & 0.21 & 1.50 & 1.72 \\
\hline Association and bargaining rights & Med. Rh & 0.09 & 0.18 & 0.54 & 0.72 \\
\hline Certified environmental management system & Med. Rh & 0.97 & 1.94 & 5.82 & 7.77 \\
\hline Child labour, total & Med. Rh & 0.03 & 0.06 & 0.18 & 0.24 \\
\hline Drinking water coverage & Med. Rh & 0.08 & 0.17 & 0.83 & 0.99 \\
\hline Education & Med. Rh & 0.12 & 0.23 & 0.69 & 0.93 \\
\hline Fair salary & Med. Rh & 0.12 & 0.23 & 0.69 & 0.92 \\
\hline Fatal accidents & Med. Rh & 0.01 & 0.03 & 0.05 & 0.08 \\
\hline Frequency of forced labour & Med. Rh & 0.01 & 0.02 & 0.11 & 0.13 \\
\hline Gender wage gap & Med. Rh & 0.27 & 0.55 & 1.09 & 1.64 \\
\hline Goods produced by forced labour & Med. Rh & 0.01 & 0.02 & 0.20 & 0.22 \\
\hline Health expenditure & Med. Rh & 0.18 & 0.36 & 0.72 & 1.08 \\
\hline Illiteracy, total & Med. $\mathrm{Rh}$ & 0.11 & 0.22 & 0.66 & 0.88 \\
\hline Indigenous rights & Med. Rh & 0.04 & 0.08 & 0.23 & 0.31 \\
\hline Non-fatal accidents & Med. Rh & 0.20 & 0.40 & 1.21 & 1.61 \\
\hline Public sector corruption & Med. Rh & 0.63 & 1.27 & 3.80 & 5.07 \\
\hline Safety measures & Med. Rh & 0.24 & 0.49 & 3.42 & 3.91 \\
\hline Sanitation coverage & Med. Rh & 0.41 & 0.82 & 4.08 & 4.89 \\
\hline Social security expenditures & Med. Rh & 0.13 & 0.26 & 0.26 & 0.52 \\
\hline Trade union density & Med. Rh & 0.92 & 1.85 & 5.54 & 7.38 \\
\hline Trafficking in persons & Med. Rh & 0.07 & 0.13 & 0.40 & 0.53 \\
\hline Unemployment & Med. Rh & 0.04 & 0.08 & 0.08 & 0.15 \\
\hline Violations of employment laws and regulations & Med. Rh & 0.10 & 0.19 & 1.74 & 1.93 \\
\hline Weekly hours of work per employee & Med. Rh & 0.01 & 0.03 & 0.05 & 0.08 \\
\hline Women in the sectoral labour force & Med. Rh & 0.09 & 0.19 & 0.19 & 0.37 \\
\hline Youth illiteracy, total & Med. Rh & 0.02 & 0.04 & 0.13 & 0.18 \\
\hline
\end{tabular}


As done for the common default thresholds addressing uncertainty in general, it is discussed whether the new specified thresholds lead to indifference between two options or even whether an indicator cannot be used at all to find a more sustainable option.

Compared to using default thresholds for impact assessment, in the LCA, more indicators show indifference between at least two options. The numbers are compared between the two threshold options (default and specified) based on impact assessment uncertainty in Figure 4. In particular, the specified comparison between hydrogen production in Germany and Spain must do without six indicators due to indifference and two more indicators fall into the category weak preference. In total, these are more than half of all proposed environmental indicators. The indicators in question come from very diverse backgrounds. For example, 'Cumulative energy demand' has the best uncertainty classification (uncertainty class 1 , cf. Table 3 ), but the result for hydrogen production in Germany is only $4 \%$ higher than for hydrogen production in Spain (cf. Table 6). In contrast, the result for 'Ecosystem toxicity, freshwater' in Germany is roughly $50 \%$ higher (cf. Table 6) than for that in Spain, but this indicator is classified as 3 (cf. Table 3) and thus even a difference of more than $50 \%$ does not lead to a clear preference. Within the LCA, 'Ecosystem toxicity, freshwater' is the only indicator which shows indifference for all discussed hydrogen production locations. The similarity of the LCA results might be explained by similar structures of electricity generation in Spain and Germany (cf. [17]). In both countries, the electricity mix of the investigated year depends on a mix of fossil and nuclear power plants as well as some renewable energy sources, whereas in Austria, a high share of electricity is generated by hydropower.

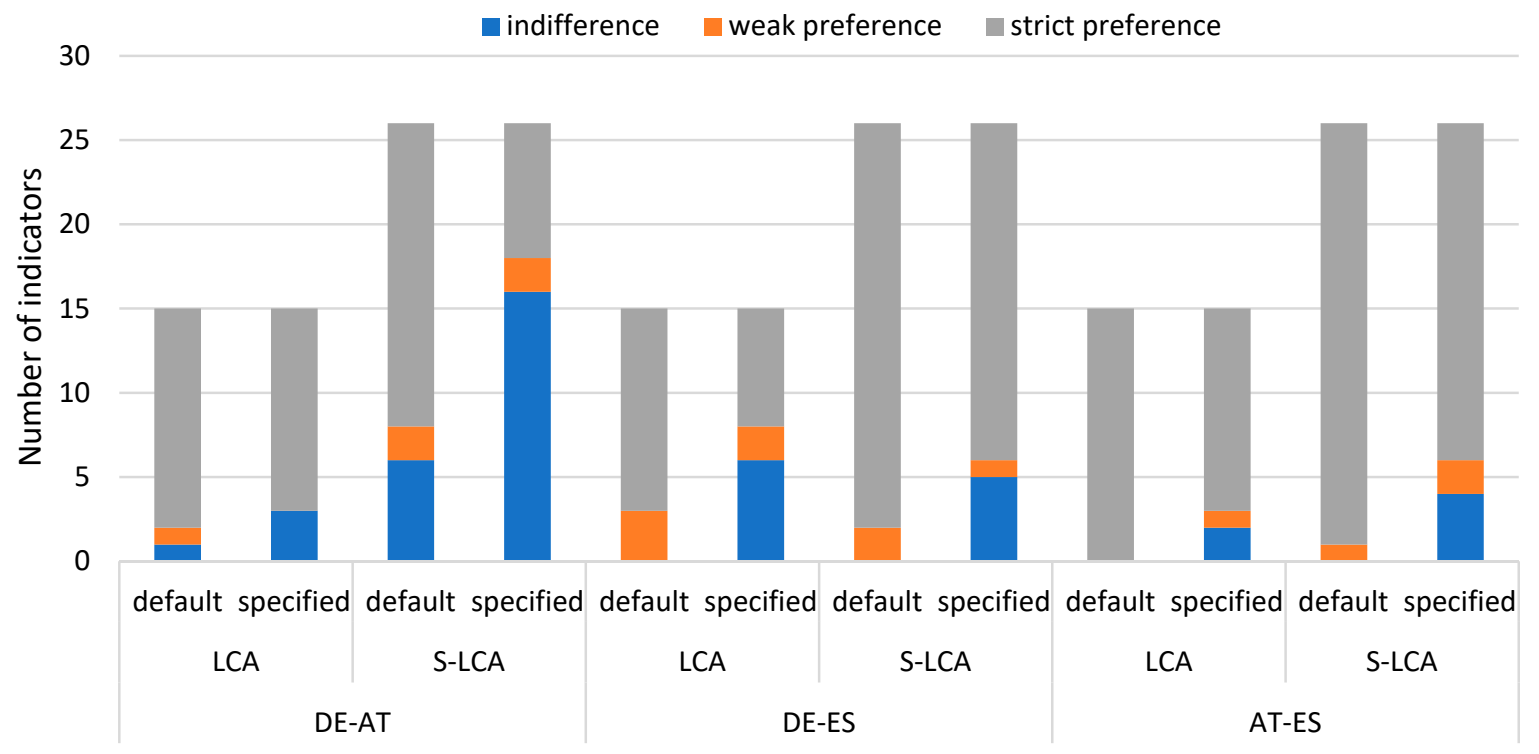

Figure 4. Numbers of indicators with strict and weak preferences and indifferences for industrial hydrogen production for default and specified thresholds regarding impact assessment uncertainty.

For S-LCA, the number of indicators showing specified indifference between at least two discussed options rises significantly, too. However, here, the proximity of indicator results is the highest for Germany and Austria. The number of indicators with indifference rises from six for the default thresholds to 16 for the specified thresholds. Including the number of indicators with weak preference, only eight indicators are left with strict preference (Figure 4) out of the 26 initial S-LCA indicators. The proximity of the S-LCA results for hydrogen in Germany and Austria might be explained by the similarity of the social systems, the regulations and the international supply chains. For the other two pairwise comparisons there are fewer effects, i.e., Germany-Spain and Austria-Spain comparisons still have $20 \mathrm{~S}$-LCA indicators to lean on. In S-LCA, some indicators do not allow to prefer one option to the other two options at all. In total, four indicators- 
indicated with bold writing in Table 8 -fall into this category. The indicators 'Violations of employment laws and regulations' and 'Goods produced by forced labour' suffer from high uncertainty, whereas for the other two indicators the options actually have very close absolute results.

In Figure 5, the PROMETHEE results of the case study are depicted for the default threshold (a) and the specified threshold (b) cases based on uncertainty of the impact assessment. In both versions, Germany is the best location for hydrogen production according to PROMETHEE I $\left(\Phi^{+}\right.$and $\left.\Phi^{-}\right)$and II $\left(\Phi^{\text {net }}\right)$. The ranking is not affected by the stricter thresholds. However, the results for the German and Austrian outranking flows are moving closer together, indicating a closer proximity of the hydrogen production in Germany and Austria compared to hydrogen production in Spain.

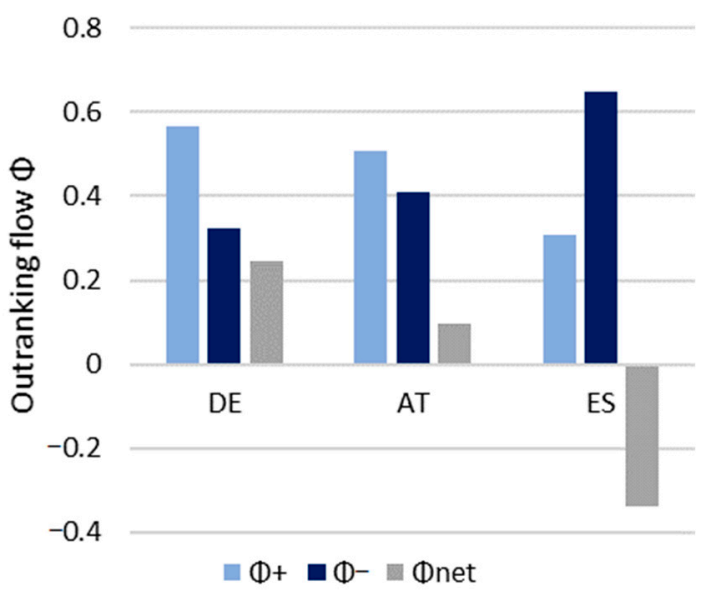

(a) Default thresholds p'Def

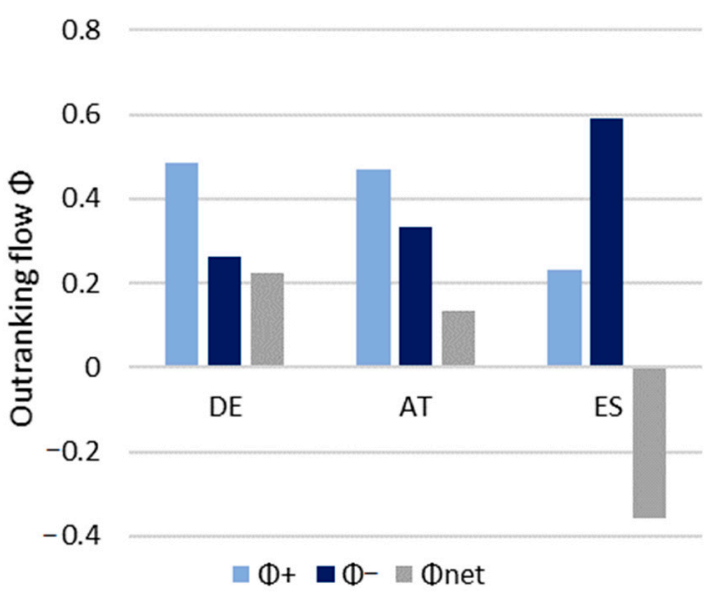

(b) Indicator specified thresholds $\mathrm{p}^{\prime}$ spec

Figure 5. Outranking results using (a) default thresholds and (b) specified thresholds based on impact assessment uncertainty.

\section{Conclusions}

Former assessments on electricity-intensive industrial hydrogen production by AEL in Spain, Germany and Austria showed different preferences with regard to the LCA, LCC and S-LCA, which advised the application of the MCDA. At the same time, the three western European countries are quite similar, making the use of an outranking method reasonable. Therefore, this case study was chosen to test the implementation of thresholds in PROMETHEE. When using PROMETHEE as an MCDA method, the implementation of thresholds has proven to be an easy and effective way for integrating uncertainty aspects. However, identifying and quantifying uncertainty is still challenging. Often, common default thresholds are used, which subsume different aspects of uncertainty. In this article, a new approach to integrate uncertainty of LCIA into LCSA studies was presented because uncertainty of LCIA is, in contrast to input data, seldom addressed in LCSA.

Within LCA, several publications already dealt with the topic of quantifying uncertainties on an impact level and have been used here for defining thresholds. For S-LCA, less information is available, and in this paper, the quantification of uncertainty is based on expert knowledge. As for the LCC, no impact assessment is used and no uncertainty for LCIA is considered. Based on this framework, we were able to identify and quantify specified thresholds to be used within PROMETHEE besides commonly used default thresholds.

The goal of the analyses was the comparison of both approaches. In a first analysis, common default thresholds were applied, which address uncertainty in general. In a second analysis, the default and specified thresholds were applied, which exclusively addressed the uncertainty of LCIA. In all analyses, a clear preference of hydrogen production in Germany compared to Austria and Spain can be found.

The common default thresholds for general uncertainties indicated that based on the economic indicators, a prioritization of Austria or Spain can rely only on one indicator. 
For three out of four economic indicators, indifference between those two countries was observed. The fourth indicator shows only weak preferences. Regarding these indicators, a more detailed analysis is advised.

The second analysis with thresholds for LCIA highlighted the indifference of several SLCA indicators for the comparison between Germany and Austria when utilizing specified thresholds. A clear preference can be determined between Germany and Austria for only 8 out of the 26 S-LCA indicators. The default thresholds for social LCIA show a comparable amount to the general results. Since by using the PSILCA database only a hotspot analysis can be performed, a more detailed analysis is needed for indicators of high interest when comparing hydrogen production in Germany and Austria. For LCA, the specified thresholds also show a decrease in indicators with clear preferences, however to a smaller degree. Especially the environmental comparison between Germany and Spain becomes less diverse, relying on seven instead of twelve indicators.

Even though both assessments came to the same result in the end, the whole process brought deeper knowledge about the results of the case study and it was proven that the obtained ranking of the three countries for industrial hydrogen production is robust, given system boundaries and inventory. Incorporating uncertainties in the LCIA methodology, however, reduces indicators showing clear preferences between all three countries down to 16 out of the 41 initial indicators. This confirms the underlying assumption of similar countries to be compared.

Still, the detailed examination of thresholds, uncertainty of LCIA and PROMETHEE helped to identify crucial points of the whole MCDA process and has shown where more detailed analyses are needed to pursue LCSA of industrial hydrogen production further.

However, relying only on the uncertainty of the LCIA is often not sufficient. Thus, an additional assessment of uncertainty and variability regarding the input data, for example, with a Monte Carlo analysis, could be helpful. Regarding the identification of uncertainty of LCIA by defining specified thresholds, more research is needed. In particular, with the identified thresholds for social LCIA we stimulate the discussion. Next, information on data quality regarding LCIA in PSILCA should be integrated.

For the validation of the new LCIA based approach, testing it on other case studies and transferring these thresholds to other MCDA methods, e.g., TOPSIS, is needed. We are confident that the approach can be transferred to other MCDA studies. Overall, this proposed approach will help to gain knowledge about the whole decision problem as well as to find robust results.

Supplementary Materials: The following are available online at https:/ /www.mdpi.com/article/10 .3390/su13137009/s1, Document 1: Minimal example.

Author Contributions: Conceptualization, C.W. and P.Z.; methodology, C.W.; validation, A.S., P.Z. and W.K.; formal analysis, C.W.; writing — original draft preparation, C.W. and P.Z.; writing-review and editing, P.Z., W.K. and A.S.; All authors have read and agreed to the published version of the manuscript.

Funding: This research received no external funding.

Institutional Review Board Statement: Not applicable.

Informed Consent Statement: Not applicable.

Data Availability Statement: Not applicable.

Acknowledgments: This work was originally presented at the Workshop "Prospektiven multidimensionalen Bewertung von Energietechnologien" on the 5 February 2019 in Oldenburg under the title "Indikatorspezifische Indifferenzzonen in PROMETHEE für Life Cycle Sustainability Assessment der Wasserstoffproduktion" by the authors of this paper.

Conflicts of Interest: The authors declare no conflict of interest. 


\section{References}

1. UN. Adoption of the Paris Agreement, Framework Convention on Climate Change; United Nations: Paris, France, 2015.

2. European Commission. The European Green Deal; European Commission: Brussels, Belgium, 2019.

3. Fuel Cell and Hydrogen Joint Undertaking. Hydrogen Roadmap Europe; Publications Office of the European Union: Luxembourg, 2020.

4. Ram, M.; Bogdanov, D.; Aghahosseini, A.; Khalili, S.; Child, M.; Fasihi, M.; Traber, T.; Breye, C. Global Energy System Based on 100\% Renewable Energy - Power, Heat, Transport and Desalination Sectors; Lappeenranta University of Technology, Energy Watch Group: Berlin, Germany, 2019.

5. IEA. The Future of Hydrogen: Seizing Today's Opportunities-Report Prepared by the IEA for the G20, Japan; International Energy Agency: Paris, France, 2019.

6. Grunwald, A.; Rösch, C. Sustainability assessment of energy technologies: Towards an integrative framework. Energy Sustain. Soc. 2011, 1, 3. [CrossRef]

7. Ciroth, A.; Finkbeiner, M.; Traverso, M.; Hildenbrand, J.; Kloepffer, W.; Mazijn, B.; Prakash, S.; Sonnemann, G.; Valdivia, S.; Ugaya, C.M.L.; et al. Towards a Life Cycle Sustainability Assessment: Making Informed Choices on Products; UNEP/SETAC Life Cycle Initiative: Paris, France, 2011.

8. Prado, V.; Rogers, K.; Seager, T.P. Integration of MCDA Tools in Valuation of Comparative Life Cycle Assessment. In Life Cycle Assessment Handbook; Wiley: Hoboken, NJ, USA, 2012; pp. 413-431.

9. Jones, M. Multi-Criteria Decision Analysis Tool; The University of Manchester: Manchester, UK, 2016.

10. OECD; JRC. Handbook on Constructing Composite Indicators Methodology and User Guide; OECD: Paris, France, 2008; p. 158S.

11. Bouyssou, D. Building Criteria: A Prerequisite for MCDA; Springer Science and Business Media LLC: Berlin/Heidelberg, Germany, 1990; pp. 58-80.

12. Monghasemi, S. Re: Why Promethee Offers More Preference Functions to Select From? Available online: https://www researchgate.net/post/Why-PROMETHEE-offers-more-preference-functions-to-select-from/55f1f9685cd9e3bbb58b45c0 / citation/download (accessed on 11 November 2020).

13. Vinodh, S.; Girubha, R.J. Promethee based sustainable concept selection. Appl. Math. Model. 2012, 36, 5301-5308. [CrossRef]

14. Valente, A.; Iribarren, D.; Dufour, J. Life cycle sustainability assessment of hydrogen from biomass gasification: A comparison with conventional hydrogen. Int. J. Hydrogen Energy 2019, 44, 21193-21203. [CrossRef]

15. Wulf, C.; Werker, J.; Zapp, P.; Schreiber, A.; Schlör, H.; Kuckshinrichs, W. Sustainable Development Goals as a Guideline for Indicator Selection in Life Cycle Sustainability Assessment. Procedia CIRP 2018, 69, 59-65. [CrossRef]

16. Ren, J.; Toniolo, S. Life cycle sustainability decision-support framework for ranking of hydrogen production pathways under uncertainties: An interval multi-criteria decision making approach. J. Clean. Prod. 2018, 175, 222-236. [CrossRef]

17. Koj, J.C.; Wulf, C.; Schreiber, A.; Zapp, P. Site-Dependent Environmental Impacts of Industrial Hydrogen Production by Alkaline Water Electrolysis. Energies 2017, 10, 860. [CrossRef]

18. Kuckshinrichs, W.; Ketelaer, T.; Koj, J.C. Economic Analysis of Improved Alkaline Water Electrolysis. Front. Energy Res. 2017, 5. [CrossRef]

19. Werker, J.; Wulf, C.; Zapp, P. Working conditions in hydrogen production: A social life cycle assessment. J. Ind. Ecol. 2019, 23, 1052-1061. [CrossRef]

20. Wulf, C.; Werker, J.; Ball, C.; Zapp, P.; Kuckshinrichs, W. Review of Sustainability Assessment Approaches Based on Life Cycles. Sustainability 2019, 11, 5717. [CrossRef]

21. UNEP. Guidelines for Social Life Cycle Assessment of Products and Organizations 2020; United Nations Environment Programme (UNEP): Paris, France, 2020.

22. Eisfeldt, F.; Ciroth, A. PSILCA-A Product Social Impact Life Cycle Assessment Database Database Version 2; GreenDelta: Berlin, Germany, 2017; Volume 3.

23. EU-JRC. Recommendations for Life Cycle Impact Assessment in the European Context-Based on Existing Environmental Impact Assessment Models and Factors; European Commission-Joint Research Centre-Institute for Environment and Sustainability: Luxembourg, 2011.

24. UNEP SETAC. Global Guidance for Life Cycle Impact Assessment Indicators: Volume 1; United Nations Environment Programme, Sustainable Lifestyles, Cities and Industry Branch: Paris, France, 2017.

25. UNEP SETAC. Global Guidance on Environmental Life Cycle Impact Assessment Indicators: Volume 2; United Nations Environment Programme, Sustainable Lifestyles, Cities and Industry Branch: Paris, France, 2019.

26. Boulay, A.-M.; Bare, J.; Benini, L.; Berger, M.; Lathuillière, M.J.; Manzardo, A.; Margni, M.; Motoshita, M.; Núñez, M.; Pastor, A.V.; et al. The WULCA consensus characterization model for water scarcity footprints: Assessing impacts of water consumption based on available water remaining (AWARE). Int. J. Life Cycle Assess. 2018, 23, 368-378. [CrossRef]

27. thinkstep. GaBi Ts; thinkstep: Leinfelden-Echterdingen, Germany, 2017.

28. Swiss Centre for Live Cycle Inventories. Ecoinvent Database Version 3.3; Ecoinvent: Zurich, Switzerland, 2016.

29. thinkstep. GaBi Databases Upgrades E Improvements: 2017 Edition; thinkstep AG: Leinfelden-Echterdingen, Germany, 2017.

30. Okano, K. Life Cycle Costing-An Approach to Life Cycle Cost Management: A Consideration from Historical Development. Asia Pac. Manag. Rev. 2001, 6, 317-341. [CrossRef]

31. Korpi, E.; Ala-Risku, T. Life cycle costing: A review of published case studies. Manag. Audit. J. 2008, 23, 240-261. [CrossRef] 
32. European Investment Bank. The Economic Appraisal of Investment Projects at the EIB; European Investment Bank: Luxembourg, 2013.

33. Branker, K.; Pathak, M.; Pearce, J. A review of solar photovoltaic levelized cost of electricity. Renew. Sustain. Energy Rev. 2011, 15, 4470-4482. [CrossRef]

34. GreenDelta. OpenLCA; GreenDelta GmbH: Berlin, Germany, 2018.

35. Andrews, E.S.; United Nations Environment Programme. Guidelines for Social Life Cycle Assessment of Products: Social and SocioEconomic LCA Guidelines Complementing Environmental LCA and Life Cycle Costing, Contributing to the Full Assessment of Goods and Services within the Context of Sustainable Development; United Nations Environment Programme: Paris, France, 2009.

36. Norris, C.B.; Traverso, M.; Valdivia, S.; Vickery-Niedermann, G.; Franze, J.; Azuero, L.; Ciroth, A.; Mazijn, B.; Aulisio, D. The Methodological Sheets for Subcategories in Social Life Cycle Assessment (S-LCA); UNEP/SETAC: Paris, France, 2013.

37. Michiels, F.; Geeraerd, A. How to decide and visualize whether uncertainty or variability is dominating in life cycle assessment results: A systematic review. Environ. Model. Softw. 2020, 133, 104841. [CrossRef]

38. Rosenbaum, R.K.; Georgiadis, S.; Fantke, P. Uncertainty Management and Sensitivity Anlayis. In Life Cycle Assessment: Theory and Practice; Hauschild, M.Z., Rosenbaum, R.K., Olsen, S.I., Eds.; Springer: Cham, Germany, 2018; pp. $271-322$.

39. Benetto, E.; Dujet, C.; Rousseaux, P. Integrating fuzzy multicriteria analysis and uncertainty evaluation in life cycle assessment. Environ. Model. Softw. 2008, 23, 1461-1467. [CrossRef]

40. Ren, J.; Ren, X.; Liang, H.; Dong, L.; Zhang, L.; Luo, X.; Yang, Y.; Gao, Z. Multi-actor multi-criteria sustainability assessment framework for energy and industrial systems in life cycle perspective under uncertainties. Part 2: Improved extension theory. Int. J. Life Cycle Assess. 2016, 22, 1406-1417. [CrossRef]

41. Ren, J. Multi-criteria decision making for the prioritization of energy systems under uncertainties after life cycle sustainability assessment. Sustain. Prod. Consum. 2018, 16, 45-57. [CrossRef]

42. Qin, Y.; Cucurachi, S.; Suh, S. Perceived uncertainties of characterization in LCA: A survey. Int. J. Life Cycle Assess. 2020, 25, 1846-1858. [CrossRef]

43. Sala, S.; Cerutti, A.K.; Pant, R. Development of a Weighting Approach for the Environmental Footprint; Publications Office of the European Union: Luxembourg, 2018.

44. Roy, B. Classement et choix en présence de points de vue multiples. Rev. Fr. D'inform. Rech. Opérationnelle 1968, 2, 57-75. [CrossRef]

45. Brans, J.; Vincke, P.; Mareschal, B. How to select and how to rank projects: The Promethee method. Eur. J. Oper. Res. 1986, 24, 228-238. [CrossRef]

46. Behzadian, M.; Kazemzadeh, R.; Albadvi, A.; Aghdasi, M. Promethee: A comprehensive literature review on methodologies and applications. Eur. J. Oper. Res. 2010, 200, 198-215. [CrossRef]

47. Brans, J.P. L'ingénièrie de la décision. Elaboration d'instruments d'aide à la décision. La méthode promethee. In $L$ 'aide à La Décision: Nature, Instruments et Perspectives d'Avenir; Nadeau, R., Landry, M., Eds.; Presses de l'Université Laval: Québec, QC, Canada, 1982; pp. 183-213.

48. Brans, J.-P.; Mareschal, B. Promethee Methods. In Multiple Criteria Decision Analysis: State of the Art Surveys; Springer: New York, NY, USA, 2005. [CrossRef]

49. Brans, J.P.; Vincke, P. Note-A Preference Ranking Organisation Method. Manag. Sci. 1985, 31, 647-656. [CrossRef]

50. Mareschal, B. How to Choose the Correct Preference Function; e-PROMETHEE Days: Rabat, Morocco, 2020.

51. Hyde, K.; Maier, H.R.; Colby, C. Incorporating uncertainty in the PROMETHEE MCDA method. J. Multi Criteria Decis. Anal. 2003, 12, 245-259. [CrossRef]

52. Ren, J.; Xu, D.; Cao, H.; Wei, S.; Dong, L.; Goodsite, M.E. Sustainability decision support framework for industrial system prioritization. AIChE J. 2015, 62, 108-130. [CrossRef]

53. Rogers, K.; Seager, T.; Linkov, I. Multicriteria Decision Analysis and Life Cycle Assessment. In Real-Time and Deliberative Decision Making; Linkov, I., Ferguson, E., Magar, V.S., Eds.; Springer: Dordrecht, The Netherlands, 2008; pp. 305-314.

54. do Carmo, B.B.T.; Margni, M.; Baptiste, P. Propagating Uncertainty in Life Cycle Sustainability Assessment into Decision-Making Problems: A Multiple Criteria Decision Aid Approach. In Designing Sustainable Technologies, Products and Policies: From Science to Innovation; Benetto, E., Gericke, K., Guiton, M., Eds.; Springer International Publishing: Cham, Germany, 2018 ; pp. 317-326. [CrossRef]

55. Ren, X.; Li, W.; Ding, S.; Dong, L. Sustainability assessment and decision making of hydrogen production technologies: A novel two-stage multi-criteria decision making method. Int. J. Hydrogen Energy 2020. [CrossRef]

56. Beltran, A.M.; Prado, V.; Vivanco, D.F.; Henriksson, P.J.; Guinée, J.B.; Heijungs, R. Quantified Uncertainties in Comparative Life Cycle Assessment: What Can Be Concluded? Environ. Sci. Technol. 2018, 52, 2152-2161. [CrossRef] [PubMed]

57. Salminen, P.; Hokkanen, J.; Lahdelma, R. Comparing multicriteria methods in the context of environmental problems. Eur. J. Oper. Res. 1998, 104, 485-496. [CrossRef]

58. Heijungs, R. Uncertainty Analysis in LCA Concepts, Tools, and Practice; Institute of Environmental Sciences (CML), Leiden University: Leiden, The Netherlands, 2010.

59. Hauschild, M.Z.; Goedkoop, M.; Guinée, J.; Heijungs, R.; Huijbregts, M.; Jolliet, O.; Margni, M.; De Schryver, A.; Humbert, S.; Laurent, A.; et al. Identifying best existing practice for characterization modeling in life cycle impact assessment. Int. J. Life Cycle Assess. 2013, 18, 683-697. [CrossRef] 
60. Humbert, S.; Rossi, V.; Margni, M.; Jolliet, O.; Loerincik, Y. Life cycle assessment of two baby food packaging alternatives: Glass jars vs. plastic pots. Int. J. Life Cycle Assess. 2009, 14, 95-106. [CrossRef]

61. Chhipi-Shrestha, G.K.; Hewage, K.; Sadiq, R. 'Socializing' sustainability: A critical review on current development status of social life cycle impact assessment method. Clean Technol. Environ. Policy 2014, 17, 579-596. [CrossRef]

62. Haase, M.; Babenhauserheide, N.; Rösch, C. Multi criteria decision analysis for sustainability assessment of 2nd generation biofuels. Procedia CIRP 2020, 90, 226-231. [CrossRef]

63. Lotfi, F.H.; Fallahnejad, R. Imprecise Shannon's Entropy and Multi Attribute Decision Making. Entropy 2010, 12, 53-62. [CrossRef]

64. Wulf, C.; Zapp, P.; Schreiber, A.; Kuckshinrichs, W. Integrated Life Cycle Sustainability Assessment-Hydrogen production as a showcase for an emerging methodology. In Towards Sustainable Future. Current Challenges and Prospects in the Life Cycle Management_LCM 2019; Kasprzak, J., Ed.; Springer: Heidelberg, Germany, 2021.

65. Koj, J.C.; Schreiber, A.; Zapp, P.; Marcuello, P. Life Cycle Assessment of Improved High Pressure Alkaline Electrolysis. Energy Procedia 2015, 75, 2871-2877. [CrossRef]

66. Hermann, H.; Emele, L.; Loreck, C. Prüfung der Klimapolitischen Konsistenz und der Kosten von Methanisierungsstrategien; Öko-Institut e.V.: Freiburg, Germany, 2014.

67. Statista. Prices of Electricity for Industrial Customers in Austria from 2008 to 2020. Available online: https:/ / www.statista.com/ statistics/596258/electricity-industry-price-austria/ (accessed on 17 May 2021). 